\title{
Islamic Banking and its Legal Validity in India
}

\author{
Arushi Dikshit* and Gayatri Pradhan**
}

\begin{abstract}
Islamic banking is an emerging model of banking which is currently practiced in several countries such as Malaysia, Indonesia, Afghanistan, Bangladesh and United Kingdom. The most intriguing aspect of Islamic banking is that it works on a purely no interest basis. Given the fact that India is a country with one of the largest Muslim populations in the world, the researchers believe it is important to understand the public awareness, acceptability and feasibility of introducing this system of banking in India. This paper primarily aims at discussing the legal viability of introducing Islamic banking in India, taking into account the current legal regime. In analyzing how forthcoming the population will be towards this banking system, a sample of the population was chosen from Pune and New Delhi and surveyed with the help of a questionnaire, leading to the inference that most people are open to the concept of interest free banking but are unwilling to accept the Islamic ideology it is derived from.
\end{abstract}

Keywords: Islamic Banking, Mudarabah, Murabah, Risk Sharing, Sharia.

\footnotetext{
* Fourth Year, BA LLB (Hons.), Symbiosis Law School, Pune; arushi.dikshit@symlaw.ac.in.

** Fourth Year, BA LLB (Hons.), Symbiosis Law School, Pune; gayatri.pradhan@symlaw.ac.in.
} 


\section{Introduction}

The origin of the modern Islamic bank can be traced back to the very birth of Islam when the Prophet himself acted as an agent for his wife's trading operations. ${ }^{1}$ Middle Ages saw the practice of Islamic finance in the Muslim world, fostering trade and business activities, becoming particularly predominant in Spain, the Mediterranean and the Baltic States, wherein Islamic merchants became indispensable middlemen for trading activities. ${ }^{2}$ It is claimed that many concepts, techniques, and instruments of Islamic finance were later adopted by European financiers and businessmen.

The underlying principle of 'Islamic banking' is based on the concept of risk sharing rather than the transferring of risk. Apart from the obvious aim of being a profitable venture for the banks themselves, the banking system gives equal importance to the fact that the borrower must not be exploited in the process. ${ }^{3}$ The banking activity in question is consistent with the principles of Sharia laws and its practical application through the development of Islamic economics. Therefore, investing in businesses that provide goods or services, solely for the purpose of profit, is considered contrary to Islamic principles and is also considered a Haraam (sinful and prohibited). E.g. - alcohol, adult entertainment etc. ${ }^{4}$

${ }^{1}$ Islamic Banking, INSTITUTE OF ISLAMIC BANKING AND INSURANCE. available at http://www.Islamic-banking.com/Islamic_banking.aspx (last visited on Aug. 30, 2015).

2 Ismail Ozsoy, Conceptual Fundamentals and Basic Features on Islamic Banking, 4(22) ECONOMIC HERALD OF DONBAS QUARTERLY (2010), available at

http://www.academia.edu/1086344/Islamic_bankingconceptual_fundamentals_and_basic_features.

${ }^{3}$ Ahmet Sekreter, Sharing of Risks in Islamic Finance, 5(2) I.B.S.U.S.J. 13, 20 (2011).

${ }^{4}$ Riaz Akhtar \& Babita Talreja, Why India Needs Islamic Banking?, Infosys Finacle, available at http://www.infosys.com/finacle/solutions/thought- 
Sharia prohibits the fixed or floating payment or acceptance of Riba (usury) for loans of money. Broadly speaking, Riba meaning interest, implies any excess compensation without due consideration, where consideration does not include the time value of the money. The rationale behind the prohibition stems from the premise that the rate of interest (whether high or low) is fixed at the very beginning and due to the impossibility of predicting the profitability of the business for which the loan is used, either the borrower or the lender would absolutely and inevitably be subjected to an injustice of financial loss in both cases. ${ }^{5}$

The economic feasibility of such a system may be best explained by way of an example. It is interesting to note that Muslims constitute about $13.4 \%^{6}$ of the population in India, i.e. approximately 152 million people. If the average monthly earning of each household is assumed to be $₹ 100$, and roughly $10 \%$ of the Muslim population deposit their money in Islamic banks, the net savings would roughly add up to ₹ 1,520 million every month. It is therefore evident that Islamic banking will supplement the realm of banking, making a significant portion of the population bankable. This paper aims to discuss whether it would be viable to introduce such a banking system in India, within the confines of law as well as public opinion regarding the same.

\section{The Indian Legal Perspective}

Despite having a sizeable Muslim population in India, it is unfortunate that there is a relatively lower financial, educational and social status amongst Muslims, as compared to other

papers/Documents/why-India-needs-Islamic-banking.pdf (last visited on Sep. 13, 2015).

5 ISMAIL OZSOZY, FAIZVE PROBLEMLERI (INTEREST AND ITS PROBLEMS) 50 (Nil Publishing House, 1994).

${ }^{6}$ Government of India, Ministry of Home Affairs, Religious Composition, Census of India, 2001: available at http://www.censusindia.gov.in/ Census_Data_2001/India_at_glance/religion.aspx. 
communities. ${ }^{7}$ The need for some sort of financial support for Muslims, has been sought time and again. The Sachar Committee Report $^{8}$ opined that the need of the hour was to improve the participation and stake of the minorities, particularly Muslims in the business of regular commercial banks, coupled with the provision for financial and other support, through initiatives built around occupations where there is a concentration of Muslims and has growth potential. Given these considerations, the Planning Commission, ${ }^{9}$ was in favour of the introduction of Islamic banking:

Another area that falls broadly in the ambit of financial infrastructure is the provision of interestfree banking. Certain faiths prohibit the use of financial instruments that pay interest. The nonavailability of interest-free banking products (where the return to the investor is tied to the bearing of risk, in accordance with the principles of that faith) results in some Indians, including those in the economically disadvantaged strata of society, not being able to access banking products and services due to reasons of faith. This non-availability also denies India access to substantial sources of savings from other countries in the region.

While interest-free banking is provided in a limited manner through Non-Banking Financial Institutions and cooperatives, the Committee recommends that measures be taken to permit the delivery of interestfree finance on a larger scale, including through the banking system. This is in consonance with the

\footnotetext{
7 National Commission for Minorities: Statutory Recommendation (2005), available at http://ncm.nic.in/sachar\%20report.pdf .

8 Sachar Report on Social, Economic and Educational Status of the Muslim Community of India (2005), available at http://www.teindia.nic.in/Files/ Reports/CCR/Sachar\%20Committee\%20Report.pdf .

9 Planning Commission, Government of India, A Hundred Small Steps: Report of the Committee on Financial Sector Reforms (2008), available at http://planningcommission.nic.in/reports/genrep/rep_fr/cfsr_all.pdf .
} 
objectives of inclusiveness and growth through innovation. The Committee believes that it would be possible, through appropriate measures, to create a framework for such products without any adverse systemic risk impact.

\section{The Constitutionality of Islamic Banking}

The doctrine of equality before law to all persons, as envisaged under Article 14 of the Constitution, outlaws discrimination. Read with Article 15, it forbids discrimination on the grounds of religion. However, as Islamic banking institutions are universal in its application to both Muslim and non-Muslim customers, any question of violation of a fundamental right does not arise. Moreover, Article 14 forbids class legislation, nonetheless positive discrimination may be made, if: 10

1. The Classification is based on Intelligible Differentia: The classification must be on reasonable grounds, which distinguishes persons or a thing grouped together and is not arbitrary. Muslims, who form the largest minority in India, are also economically backward, ${ }^{11}$ essentially forming a class by themselves.

2. Nexus between the Classification and the Objective sought to be achieved: The differentia adopted as the basis of classification must have a rational or reasonable nexus, with the aim sought to be achieved by the statute. There is undoubtedly a connection between the object and the classification made, through the enactment of a separate legislation which aims to tap into the minority market, reduce financial disparity and bring about equality in the true sense. Therefore, enacting and implementing a special law on the basis of Sharia banking is necessary and desirable.

10 Laxmi Shankar v. State of Uttar Pradesh, A.I.R. 1981 S.C. 837.

11 Muslims, World Directory of Minorities and Indigenous Peoples, available at http://www.minorityrights.org/5653/india/muslims.html, (last visited on Sep.12, 2015). 


\section{Implied Prohibition of Islamic Banking is Unconstitutional}

The principle of equality does not mean that everyone is treated alike. It is well settled that likes should be treated alike. ${ }^{12}$ This includes, firstly, equals should not be treated unequally. Hypothetically speaking, if the two banking institutions are the same, then, by treating two 'persons' unequally, the law (The Banking Regulation Act, 1949) itself is unconstitutional, with an implied prohibition on Islamic banking and; secondly, unequal's should not be treated equally. Assuming that the two forms of banking are distinct and not 'equal', then by treating two unlike persons equally (subject to the same laws and statutory requirements), the law prohibiting the Islamic banking system violates Article 14.

\section{Judicial Opinion on Recognising Islamic Banking}

The question of the recognition of Islamic banking was raised before the honourable apex court in Commissioner of Wealth Tax, Bhopal v. Abdul Mhd. Ali,13 wherein the issue was whether an interest free loan given by the assesse would amount to tax deductions. Ruling in favour of the appellants, the Court held that "we are afraid both the Tribunal and the High Court accepted, somewhat liberally perhaps, what was at best an argument of hypothetical probabilities." On the other hand, it also observed that "we do not want to be understood to have pronounced on the subject finally to support the particular incidents of the nonexistence of the element of repayability attributed to this kind of loans."

The stand was still unclear when the Kerala High Court in Dr. Surbahmaniam Swamy v. State of Kerala ${ }^{14}$ faced a challenge as regards the secular aspect of the Islamic banking regime. Kerala State Industrial Development Corporation (KSIDC) had been roped in by the State government to check the viability of introducing interest free banking. Answering affirmatively, the government

12 Gauri Shankar v. Union of India, A.I.R. 1995 S.C. 55.

13 Commissioner of Wealth Tax, Bhopal, 1988 A.I.R. 1417.

${ }^{14}$ Dr. Surbahmaniam Swamy, W. P. (C).No. 35180 of 2009 (Jan. 27, 2011). 
had decided to incorporate a company for the same with some equity from KSIDC (public funds).

The Court rightly declared:

Such payment would be made to a corporate body which proposes to carry on the business in compliance with certain principles based on the religious text of a particular religion, but not to propagate religion. In our view, such a payment would not have the primary and direct effect of supporting or maintaining the religion.

\section{Interpreting the Existing Statutes}

The Reserve Bank of India (RBI) currently monitors and regulates all banking and non-banking financial institutions. Any introduction of Islamic banking system in India would therefore necessarily entail the authorization from the apex bank as a prerequisite. The most widely misconceived notion seems to be that the current banking laws prohibit interest free lending, which is the very basis of Islamic banking. ${ }^{15}$ A careful look at our banking norms seem to indicate otherwise.

\section{Reserve Bank of India Act, 1934}

Section 17(1) authorizes the RBI to transact in businesses involving the accepting of money on deposit, without interest, from the Central and State Governments, local authorities, banks and any other person. Therefore, prima facie, only the RBI is empowered to undertake Sharia Banking.

15 RBI rules out introduction of Islamic Banking, Times of India, (Nov. 22, 2012) available at, http://timesofindia.indiatimes.com/business/indiabusiness/RBI-rules-out-introduction-of-Islamic-

Banking/articleshow/17323922.cms. 


\section{The Banking Regulation Act, 1949}

As per Section 5(b), 'banking' means accepting, for the purpose of lending or investment, of deposits of money from the public, repayable on demand or otherwise, and withdrawal by cheque, draft, or otherwise. Section 5(c) defines a 'banking company' as any company which transacts the business of banking in India.

It is thus evident that the definitions of banking and banking company do not make any mention of interest as a prerequisite. The explanation attached to the Section only prohibits the usage of the term 'bank' for any company engaged in manufacturing or trading, which accepts deposits for its own financing. To gain clarity on this issue with respect to the Islamic banking model, it is pertinent to define the terms Mudarabah and Murabaha.

Mudarabah is venture capital funding of an entrepreneur who provides labour while financing is provided by the bank so that both profit and risk are shared. Such participatory arrangements between capital and labour reflect the Islamic view that the borrower must not bear all the risk/cost of a failure, resulting in a balanced distribution of income thereby preventing the lender from monopolizing the economy. In the event of loss, the capital owner bears all the loss and the principal is reduced by the amount of the loss. It is the risk of loss that entitles the capital owner to a share in the profits. The manager bears no financial loss, because he has lost his time and his work has been wasted. ${ }^{16}$

In an Islamic mortgage transaction, instead of lending money to purchase the item, a bank might buy the item itself from the seller, and re-sell it to the buyer at a profit, while allowing the buyer to pay the bank in installments. This concept refers to the sale of goods at a price, which includes a profit margin, agreed upon by both the parties. However, the bank's profit cannot be made explicit and therefore there are no additional penalties for late payment. The bank is compensated for the time value of its money in the form of the profit margin. In order to protect itself against

16 Islamic Banks Commercial Transactions, Financial Islam - Islamic Finance, available at http://www.financialislam.com/investment-andtransactions.html (last visited on Sep. 13, 2015). 
default, the bank asks for collateral. This is the concept of Murabaha. ${ }^{17}$

In the present context of this Section, the profit sharing arrangement under Mudarabah is prohibited, whereas Murabaha, which involves resale of goods at a profit margin, can be brought within the purview of banking, since unlike the concept of Mudarabah, Murabaha does not involve deposits for the purpose of financing any aspect of 'trade' of the bank, which is a prohibited activity.

Section 8 prohibits the direct or indirect dealing in buying, selling or bartering of goods, except in connection with the realization of security given to or held by it. Since the asset of the customer basically forms a security in Murabaha transactions, the same cannot be claimed to be prohibited. Section 9 prohibits banks from selling off any immovable property attached to the bank except as required for its own use.

Section 11(2A) states that on the recommendations of the RBI, the requirements of minimum paid up capital and reserves may be waived off by the Central government which is essential for the effective implementation of the Islamic banking principles. Section19(e) on the other hand permits companies to form subsidiaries, with the prior sanction from the RBI, if such an undertaking is declared to be conducive to the widespread access to banking in India, a criterion fully met by Islamic banking.

A combined reading of Section 21 (1) and 21(2) (e) makes it evident that the RBI is empowered only to control the rate of interest of banks. Thus, contrary to popular misconception, these provisions only instill in the RBI, the power to set the rate of interest to be charged by banks. A bare reading of the section, in no way indicates that it is mandatory for interest to be levied and thus, the RBI may declare Islamic banking to be permissible.

In spite of the relative grey areas in the banking provisions, public opinion seems to indicate that introducing Islamic banking would contradict the aforementioned laws. As of 2007, 2010 and 2011, the

${ }^{17} I d$. 
RBI was mulling over the introduction of Islamic banking system in India. However the erstwhile RBI Governor, Mr. D. Subbarao ${ }^{18}$ was of the opinion that unless the concerned laws are amended, implementation of such a concept would not be a viable option.

A way out of this seemingly impossible conundrum was to sanction 'Islamic banking' to be practiced by Non-Banking Financial Institutions (NBFIs) which would of course, be regulated by the RBI. Giving due regard to this alternative, in 2013, the RBI gave its approval to the Kerala State Industrial Development Corporation to float Cheraman Financial Services Limited (CFSL) to function as a Sharia based Non-Banking Financial Institution with an authorized capital of ₹ 1,000 crore.

The body would desist from charging interest on loans or providing interest on deposits. With focus on sectors like infrastructure, services and manufacturing, it would keep off areas including liquor, tobacco and gambling or speculation. ${ }^{19}$ The move might boost Kerala's remittance driven economy. It has been reported that close to ₹ 50,000 crore of interest money is lying unclaimed with Kerala banks, most of which is remittance from Kerala Muslims working in the Gulf and other foreign countries, as under Sharia they cannot claim interest from banks. ${ }^{20}$ Furthermore, in what is undoubtedly a step in the right direction, as of 2014, India is planning to set up a body to refine and promote Islamic finance before issuing license to start fully fledged banking

18 Supra, note 16.

19 Bernardo Vizacino, RBI allows non-bank Islamic finance firm, Reuters, (Aug. 20, 2013), available at http://in.reuters.com/article/ 2013/ 08/ 20/ Islamic-finance-india-idINDEE97J07L20130820.

20 First Sharia-based NBFC to open in Kerala after RBI nod, Economic Times, (Aug. 18, 2013), available at http:/ / articles.economictimes.indiatimes.com/ 2013-08-18/news/41422724_1_Islamic-banking-nbfc-Islamic-financeprinciples. 
operations, according to Mr. Rahman Khan, India's Minister for Minority Affairs. ${ }^{21}$

\section{Recommendations for Introduction of Islamic Banking System}

The current legal framework is vague at best and necessitates the need for a uniform statutory regulation, governing all forms of Islamic banking. Viable options would include:

I. Inserting, by way of amendments, new provisions into the existing laws that expressly allow and authorize Islamic banking and lay down regulatory procedure for the same. This would ensure that the system would be under supervision of an appropriate authority, like the RBI. However, it would call for the existence of Sharia law experts on the board of the RBI or its committees for the purposes of interpretation, in case of conflicts.

II. Enacting a separate law along the lines of the (Malaysian) Islamic Banking Act, 1983, that would not substitute but merely supplement the current banking framework, which provides a parallel form of banking. A palpable problem would be the constitution, powers, duties and functions of a new regulatory authority with adequate knowledge of Sharia principles.

III. RBI itself could open a branch based on the Islamic banking system in 'public interest', since they are empowered under Section 17(2) of the RBI Act, 1949 to accept interest free deposits.

IV. Giving the control and supervision of such non-profit banks to National Bank for Agriculture and Rural Development (NABARD), which already monitors co-operative societies and other financing institutions related to agricultural development.

21 Ashraf Padanna, India Takes Key Step toward Full-Fledged Islamic Banks, Arab News, (Feb. 18, 2014), available at http://www.arabnews.com/ news/ 527476. 


\section{Awareness and Acceptability of Islamic Banking in India}

The legal viability of introducing the Islamic banking system in India having been discussed, it is equally crucial to have a better understanding about the awareness and acceptability such a system would have amongst India's diverse population. A survey was conducted by the researchers at the grass root level to understand as to how forthcoming the public at large would be, in a situation where such a banking system is introduced in India.

\section{Details of the Sample Survey Conducted}

To examine the level of perceived awareness and attitude of Indians towards Islamic banking, a questionnaire containing 10 questions was formulated. For this study, data was collected through an exploratory randomized sample survey of 40 participants from Delhi and Pune, who were required to answer questions in either 'Yes, No, or Maybe'. The questions posed were ordered in a manner so as to gauge their attitude towards the banking system. The questionnaire is given below:

1. Have you heard of a new banking system that involves no payment of interest?

2. Under this system of banking, instead of lending/providing loans to the buyer to purchase an item, a bank might buy the item itself from the seller, and resell it to the buyer at a profit, while allowing the buyer to pay the bank in installments. Would you be interested in knowing more about this banking system?

3. Do you think this form of banking will specially benefit the comparatively poorer sections of the society?

4. Do you think it is viable to introduce such a banking system in India?

5. Even with the introduction of this banking system, would you still prefer the conventional banking system?

6. This is a form of Islamic banking, which functions on Sharia law. Islamic banks function on the basis of sharing profits and losses. Do you think ways of incorporating this banking system in India should be explored? 
7. Malaysia is viewed as the largest centre for Islamic finance outside the Middle East. If Islamic banking is introduced in India, would you be willing to try it out?

8. If No or Maybe, do you apprehend that the Islamic form of banking will only benefit the Islamic population in India?

9. Islamic banking is an absolutely secular form of banking that only follows principles of charging no interest based on Sharia law. Do you still think it is viable to introduce it in India?

10. The RBI has rejected this proposition on various grounds. In your opinion, should the RBI reconsider introducing it in India?

It must be noted, that the first few questions were drafted in a manner as to gauge the awareness amongst people regarding the existence of a form of interest free banking. Subsequent questions gave more information about the banking system in question, and then aimed at finding out people's opinion on whether they believe such a system should be further explored in India and would be viable upon introduction in India.

The latter half of the questionnaire disclosed the fact that the banking system in question is in fact the Islamic system of banking which is followed in several countries. We consciously decided to make this disclosure in the latter half of the questionnaire, to note if there would be a change in attitude of the respondents on discovering it is based on the Islamic ideology. Finally, we asked whether people think the RBI should reconsider introducing the Islamic banking system in India.

\section{Findings from the Survey}

The respondents were divided into three distinct age groups-below 30 years of age, 30 to 50 and 50 plus. The results of the primary data were analyzed separately with respect to each age group, to draw the most logical inferences regarding the awareness and acceptability of the Islamic banking regime. 


\section{Below 30 years}

The first set of questionnaires was distributed amongst students, primarily in the age group of 18-25. The answers to the first few questions suggest that $90 \%$ of the young adult population had no idea that such a banking system exists in any part of the world, while only a negligible $10 \%$ were informed about the existence of such a banking system. People were open to know more about the banking system, and a majority thought it may be beneficial if introduced in our country.

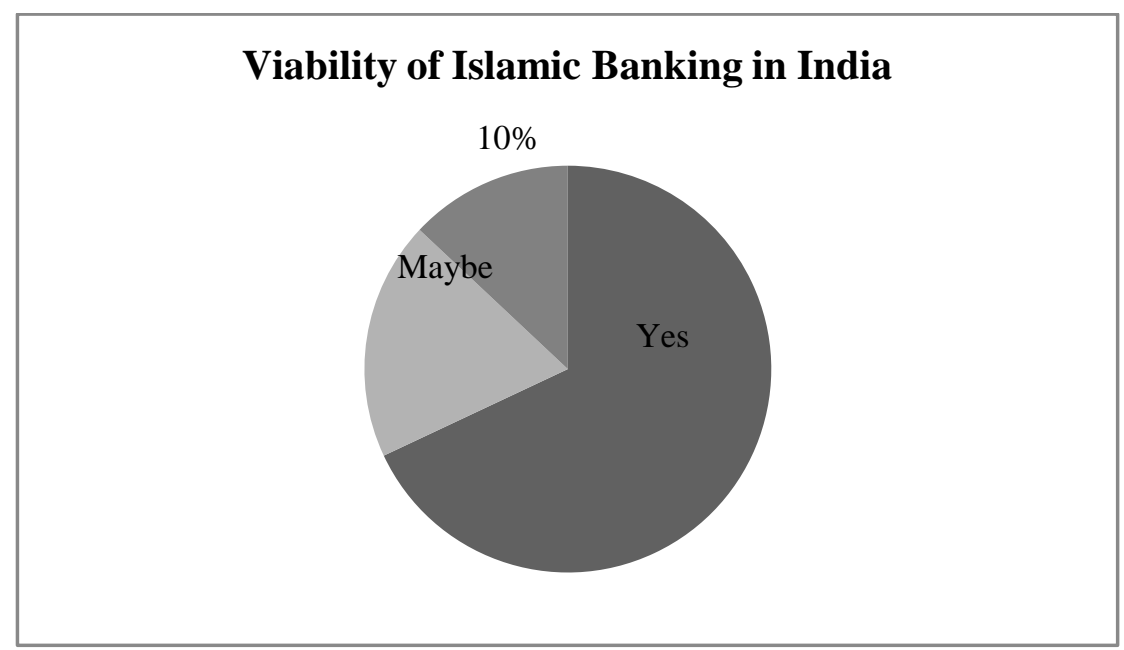

Fig 1. Opinion of respondents, below 30 years of age

Question 6 of the questionnaire disclosed the fact that the banking system being spoken about is the Islamic banking system, which enabled us to ascertain whether acceptability of the banking system was altered accordingly. Such disclosure had almost no effect on people of this age group. Since the awareness of people amongst this age group was noted to be significantly low, it is no surprise that on disclosure, $70 \%$ thought that the banking system would only benefit the Muslim community in India. However, in the subsequent questions when informed that it is an absolutely secular form of banking, $90 \%$ were of the opinion that the RBI should reconsider introducing this concept in India. 


\section{0-50 years}

The same set of questions, when further distributed amongst the working class, aged between 30 to 50 years of age resulted in a rather disquieting discovery that the awareness of the existence of such a banking system was seen to be poor amongst this class, at a mere $20 \%$. These participants comprised of a pool of engineers, management consultants, businessmen and bureaucrats.

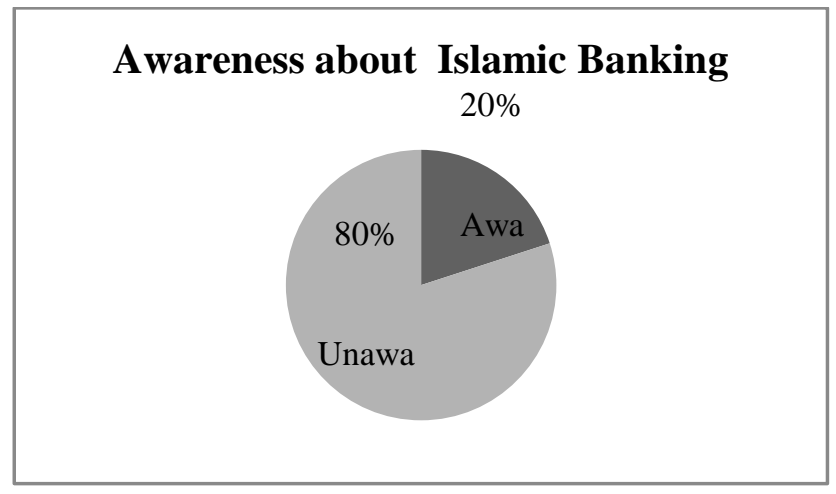

Fig 2. Awareness amongst the working class.

With respect to acceptability, $62 \%$ of the middle aged population has shown a welcoming response to the Islamic banking ideology on being informed about the basic principle of no interest. Among this age group, there was little change in acceptability that was noticed post disclosure of the term 'Islamic'. Where $27 \%$ of the working class remained unsure of the prospects, $11 \%$ showed a completely negative attitude in knowing more about the concept.

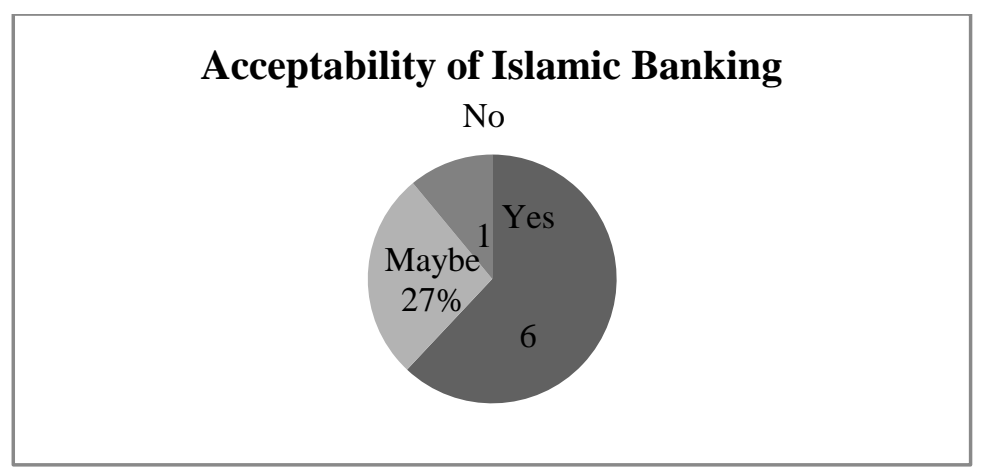

Fig 3. Acceptability amongst the working class. 


\section{Above 50 years}

Finally, from the questionnaires that were filled out by people who were aged 50 years and above, the most interesting findings were observed. We noted the maximum change in attitude towards the banking system on disclosure of it being 'Islamic' amongst this age group. While the concept of no-interest banking was one that the people were intrigued by, on information that this form of banking is based on Islamic ideology, a stark change in attitude was noted. The numbers in this regard are as described below.

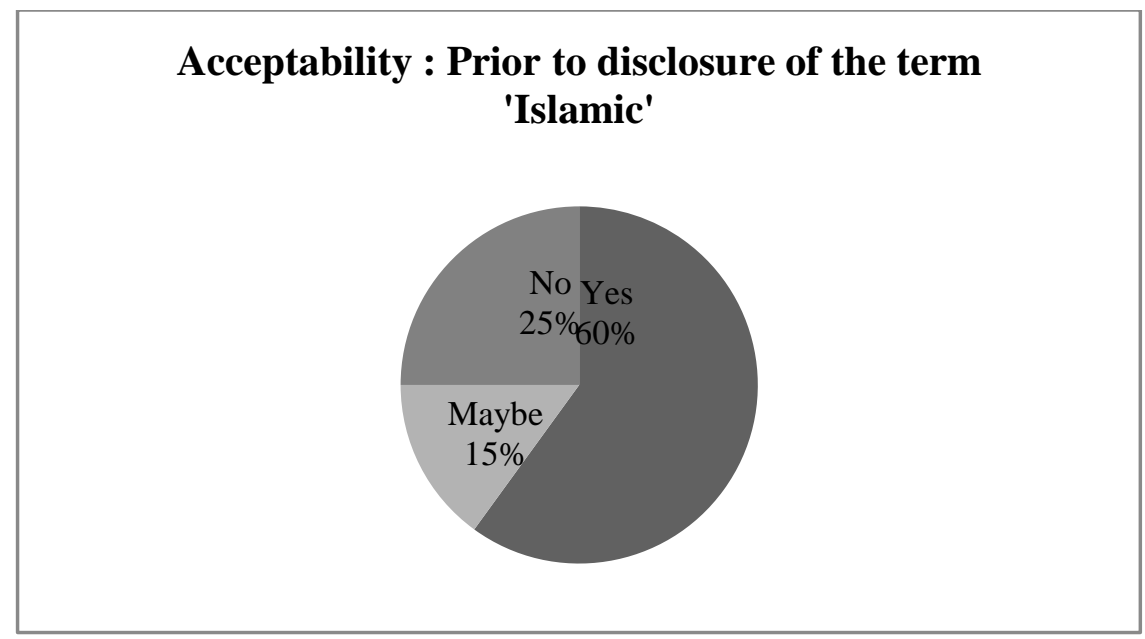

Fig 4 : Opinion of population aged above 50 years.

$60 \%$ of the people who answered the questions before they knew the banking system in question was Islamic, welcomed the idea and wanted to know more about it. $15 \%$ were unsure, and the remaining $25 \%$ said they would prefer to stick to the conventional banking system and didn't want to explore this new banking system. However, as soon as the $6^{\text {th }}$ question disclosed that the banking system referred to is based on principles of Sharia law, the acceptability of the ideology of the Islamic banking system was seen to drop drastically. Out of the $65 \%$ who initially welcomed the concept, only $20 \%$ still maintained that it was acceptable. $25 \%$ were unsure, and as much as $55 \%$ of the people decided that it is not viable to introduce such a concept in India. 


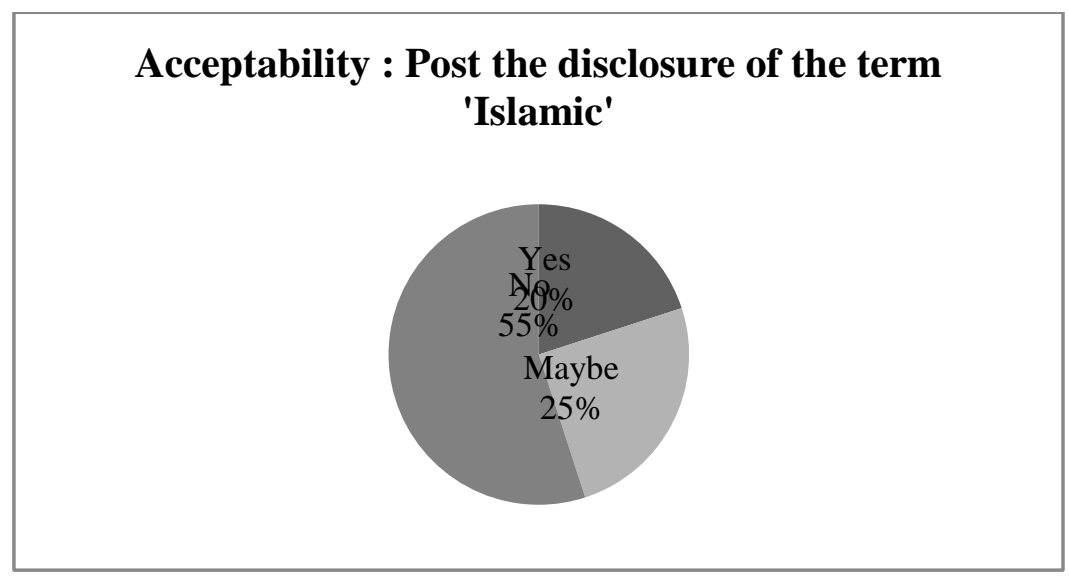

Fig 5. Change in opinion of people aged above 50 years.

\section{Analysis of the Survey Findings}

Analysis of the results on the basis of the primary data collected through means of a survey involving distribution of questionnaires, the researchers found that in general, as much as $90 \%$ of the population is intrigued by the concept of a banking system involving no payment of interest or Riba. All of them reacted positively, and wanted to explore this banking option. However, when the word 'Islamic' is attached to the banking system, or on discovering that non-payment of interest is in fact a principle of Sharia law, a large portion of the population, particularly the elderly section of Indian population, were seen to have displayed a severely biased and conservative approach to the banking system. This sentiment may be for a variety of reasons related to religious beliefs and the popular myth that such a banking system would only benefit the Muslim population of the country.

Having noted this change of attitude amongst the elderly sections of our society, it is pertinent to throw light on the fact that the younger sections of society have shown a very positive attitude and are open to knowing more about the Islamic banking system. The sections of population aged below 25 years are the ones who will be making the largest contribution to the country's GDP in the coming years. They form the majority of borrowers and expected to 
undertake important investments. Since their attitude as per our survey is seen to be the most positive with respect to the Islamic banking system ( $90 \%$ of respondents think the RBI should explore ways of introducing this banking model in India), it is vital for the RBI to reconsider introducing this system.

An important reason that is stopping this banking system from being introduced in India is the fact that people are ill informed and apprehend the secular nature of the banking model. Spreading awareness on the banking system, and scrutinizing its merits and demerits must be undertaken by the government as well as the media so that the population at large, are given an opportunity to make an informed choice.

\section{Conclusion}

In the present study, the researchers have aimed at analysing the two most important aspects to be considered while introducing Islamic banking in India, namely its legal viability and public opinion. It is unfortunate that Muslims form one of the most economically backward classes of citizens in this nation and any efforts to bring about their financial inclusion must be construed liberally, so as to bring about their financial independence and equality in its truest sense. The data gathered clearly showed that the attitude of most Indians towards interest-free banking remains positive.

The matter of utmost importance is to make people aware that like any system that is introduced for the public at large, the Islamic system of banking, is not communal or divisive and provides benefits which are open to all. The word Islamic attached to it must not be prejudicially assumed to derive any other meaning other than its most fundamental ideology of nonpayment of interest. Their technical viability or legal standing or moral worth has to be judged on their methods, operations and benefits to the society. 